\title{
Undergraduate Students' Perception and Attitudes towards Teaching Profession in University of Benin, Nigeria
}

\author{
Dr. Vivian E.I. Audu \\ Department of Educational Psychology and Curriculum Studies, \\ Faculty of Education, University of Benin, Benin City \\ Dr. John Egharevba \\ Department of Educational Psychology and Curriculum Studies, \\ Faculty of Education, University of Benin, Benin City
}

\section{Doi:10.5901/jesr.2016.v6n1p184}

\begin{abstract}
The study investigated the perception and attitude of education students towards teaching as a profession, a case study of the University of Benin, Benin City. The descriptive survey research design was adopted. Three research questions were answered. Stratified random sampling technique was used to obtain a sample of one hundred and twenty (120) students. A self constructed instrument was validated and used to collect data for the study. Data collected were analyzed using simple percentage. Results showed that the perception and attitude of education students toward teaching is not influenced by sex; parents had negative perception and attitude toward their children studying education; and students are not willing to take up teaching job because of low status, poor condition of service of teachers and negative perception of teaching profession by the society. A major recommendation offered suggests that counselors should organize counseling interventions, seminars and workshops for students, parents, teachers and society at large to develop positive perception and attitude towards teaching profession.
\end{abstract}

Keywords: Education Students, Perception, Attitude, Teaching Profession, Sex, Parents

\section{Introduction}

Education is an important instrument for enhancing national development, such development can be seen in the positive roles education plays in the socio-cultural, political, economic and human aspects of nation building. Education is the key to participating in the highly competitive economy of the $21^{\text {st }}$ century. It fosters scientific and technological advancement which are the modern day indices for national development. The term education is got from the Greek word "educare" which means to "lead out". Therefore, education can be defined as the total process of human learning by which knowledge is imparted, faculties trained and skills developed (Urevbu, 1991). Nigeria is not left out of the realization of this paramount role of education. As stated in the National Policy on Education (2004), "education shall be highly rated in the national development plans because it is the most intellectual and social outlook of any society that has to be preceded by educational revolution; efforts shall be made to relate education to overall community needs". As important as education is to personal and national development, its effect can only be felt if the citizens acquire skills and knowledge that would enable them to contribute their quota to their immediate family and the society at large. For education to serve its purpose, teachers have a role to play in the implementation of the objectives and goals. No educational programme can be effectively implemented and achieved without teachers.

\section{Literature Review}

The role of a teacher in personal and national development cannot be over emphasized in view of the fact that all those who work to build a nation are individuals who had undergone one form of educational training or the other and would have been taught by teachers. Abdulkareem (1997) observed that "even though there are constant cultural, functional and technological changes in our way of living, the teacher remains the key factor in the educational system". The teacher's influence on students' future career and what they may become is expressed by Fafunwa (1972), who opined 
that poorly trained teachers will affect students' motivation for teaching profession and produce poorly trained professionals in teaching and other fields.

Education is a course that most students are unwilling to apply for in Joint Admission and Matriculation Board (JAMB) because of their negative perception about teaching. Most students admitted into the education faculties and colleges of education in Nigeria, do not have interest in studying education because they do not have the intention of becoming teachers at the end of the programme; they only accepted to study education because they failed to get admission into their preferred course(s). They see it as a stepping stone to other professions. Those in the colleges of education are there because they could not score the required marks in JAMB. Such students tend to have negative attitude towards teaching profession.

Teaching no longer attracts favourable attention from the public and society; also, the high rate of indiscipline and arrogance exhibited by children could have influenced student teachers to develop a wrong perception and become unwilling to go into teaching after graduation. Aghenta (1981), opined that teachers are denied kind words and encouragement; their salaries may be fat but not regularly paid and allowances are reduced. Education administrator threaten them, students treat them with disrespect while members of the public refuse them sympathy. Consequently, they are frustrated with many of them thrown out of job without regard to the fact that they have undergone any training.

The National Policy on Education (FGN, 2004), stated that one of the ways of making teaching a profession is through teaching practice which is similar to the industrial training and internship done by engineering and medical professions respectively. According to Afe (1990), teaching practice exercise is to the teacher in training what internship is to the medical doctor or apprenticeship to the technicians. Omoregbe (2004), emphasized that teaching practice is imperative for training competent teachers for the efficient operation of our education and the realization of national objectives. Secondary school students pursuing post secondary and higher education courses in the field of teaching will be well equipped to practice the profession after training.

The fate of teachers in Nigeria today as perceived by the society and the government in particular also affects the education students' perception and attitude toward the teaching profession. An educated populace is of great importance to every nation, increased awareness, economic growth and technological advancement are made possible through education and the efforts of the teacher. A teacher requires good teaching conditions and conducive environment to perform and function effectively. The government in the National Policy on Education appears to be making conscious effort towards improved working conditions and environment for teachers; the efforts are however thwarted by people charged with the responsibility of ensuring that the policies are effectively implemented.

The government may have contributed to some of the problems the teaching profession faces today. The problems of irregular payment of salaries, under funding of schools, poor teaching conditions among others may be responsible for the way, teaching profession is perceived by students, parents and the society.

Therefore, the researchers intend to investigate whether sex (male/female); parental influence and teaching conditions would affect the perception and attitude of education students towards teaching profession.

\section{Objectives of the Study}

1. To investigate if sex influences the perception and attitude of education students towards teaching profession.

2. To investigate if parental influence affects the perception and attitude of education students towards teaching profession.

3. To investigate if teaching condition influences students' perception and attitude to teaching profession.

\section{Research Questions}

1. Does sex influence the perception and attitude of education students towards teaching profession?

2. Does parental influence affect the perception and attitude of education students teaching profession?

3. Can teaching condition influence education students' perception and attitude to teaching profession?

\section{Methodology}

The target population for the study consisted of all undergraduate education students at the 300 and 400 levels of the University of Benin. The sample size comprised one hundred and twenty (120). The stratified random sampling technique was used to select the sample size. The population was divided into two strata (300 and 400 levels) each; 
each level was subdivided into five (5) departments of the faculty; namely Adult Education (ADE), Educational Studies and Management (ESAM); Educational Psychology and Curriculum Studies (EPCS), Health, Environmental Education and Human Kinetics (HEK) and Vocational and Technical Education (VTE). The students were further stratified into male and female and the sex of the students randomly selected, twelve (12) from each department giving sixty (60) from each level (300 and 400 levels) making a total of one hundred and twenty (120) respondents.

The research instrument was a self constructed questionnaire which was on the perception and attitude of education students towards teaching profession. The research instrument has a test-retest reliability coefficient of 0.95 using the split-half technique. The research instrument is divided into two sections. Section A consists of demographic information from respondents such as age, marital status and level of study. Section B had twelve items which sought respondents' opinions on their perception and attitude towards teaching profession.

Data Analysis: The data collected were analyzed using frequency counts and simple percentages.

\section{Results}

One of the major objectives of the study was to determine the factors considered to influence the perception and attitude of education students towards teaching profession. Data collected from respondents were subjected to descriptive statistics and presented as follows:

6.1 Research Question 1: Does sex influence the perception and attitude of education students towards teaching profession?

Table 1: Influence of Sex on Education students' perception of Teaching Profession

\begin{tabular}{|c|l|c|c|c|}
\hline \multirow{2}{*}{ S/N } & ITEMS & \multicolumn{2}{|c|}{ RESPONSES } & \multirow{2}{*}{ FREQUENCY } \\
\cline { 3 - 5 } & YES & NO & FR \\
\hline 1. & Is teaching profession mainly for the females? & 19 & 101 & 120 \\
\hline 2. & Is the teacher's reward more adequate for the females than the males? & 30 & 90 & 120 \\
\hline 3. & Are male teachers more actively oriented towards teaching profession than the female? & 50 & 70 & 120 \\
\hline 4. & Are female teachers more satisfied than males with teaching job? & 21 & 99 & 120 \\
\hline & TOTAL & $\mathbf{1 2 0}$ & $\mathbf{3 6 0}$ & $\mathbf{4 8 0}$ \\
\hline & PERCENTAGES & $\mathbf{2 5} \%$ & $\mathbf{7 5 \%}$ & $\mathbf{1 0 0 \%}$ \\
\hline
\end{tabular}

Table 1 above shows that $75 \%$ of the respondents do not see teaching as a profession for only a particular sex, while $25 \%$ of the respondents see teaching as a profession for a particular sex. It indicates that sex does not influence education students' perception and attitude to teaching.

6.2 Research Question 2: Does parental influence affect the perception and attitude of education students towards teaching profession?

Table 2: Parental Influence on education students' perception and attitude to teaching profession

\begin{tabular}{|c|l|c|c|c|}
\hline \multirow{2}{*}{ S/N } & \multirow{2}{*}{ ITEMS } & \multicolumn{2}{|c|}{ RESPONSES } & \multirow{2}{*}{ FREQUENCY } \\
\cline { 3 - 4 } & & YES & NO & FRE \\
\hline 5. & Did your parents influence your choice of study? & 44 & 76 & 120 \\
\hline 6. & Do your parents have a positive attitude or opinion to your studying education? & 38 & 82 & 120 \\
\hline 7. & Are they sincerely in support of your studying education? & 81 & 39 & 120 \\
\hline 8. & Do your parents want you to study another course after studying education? & 48 & 72 & 120 \\
\hline & TOTAL & $\mathbf{2 1 1}$ & $\mathbf{2 6 9}$ & $\mathbf{4 8 0}$ \\
\hline & PERCENTAGES & $\mathbf{4 3 . 9 6 \%}$ & $\mathbf{5 6 . 0 4 \%}$ & $\mathbf{1 0 0 \%}$ \\
\hline
\end{tabular}

Table 3 shows the influence of teaching conditions on education students' perception and attitude to teaching profession. The result reveals that most education students are discouraged from going into teaching profession because of poor teaching conditions and poor status. $60.4 \%$ of the respondents agree that poor teaching conditions and reward system influenced their perception while $39.6 \%$ of the respondents disagreed. 


\section{Discussion}

The result of research question one showed that the perception and attitude of education students toward the profession of teaching do not differ according to sex (male and female); the analysis revealed that teaching is not seen as predominantly a feminine profession. The study of Odunisi (2004) corroborates the findings of this study. He found that "students" gender or class of students does not significantly influence students' attitude towards choices of profession". It therefore means that the teaching profession has no fender discrimination irrespective of perceived economical and living standards peculiar to the profession of teaching.

The findings of the study on whether parental influence affects the perception and attitude of education students toward teaching profession revealed that although most parents have negative attitude and opinion towards their children's choice of education, parents did not influence their current choice of study. However, they tend to influence their children's attitude towards the profession negatively. The implication of this is that most parents who are in a better position to positively project teaching profession tend to look down on teachers and the teaching profession, and this corroborates the study of Ogumogu (2006), who found that "parents who are supposed to influence their children by motivating and supporting them to go into teaching profession do not, but they later appreciate it as a last resort because their children could not be admitted into their preferred course(s) of choice".

The result of research question three revealed that education students are not attracted to teaching because of the low status and poor conditions of service of teachers. Ekhabafe (2007), reported the low status and poor salary of teaching profession in Africa. He further stated that what teachers earn is not enough to maintain a standard of life comparable to that of other individuals having the same qualification. It is not surprising that most education students are discouraged from taking up teaching job but the good news is that the study also showed that a good number of education students intend to take up teaching appointment after graduation because they love teaching profession.

\section{Counselling Implication}

Since most counselors are found in schools where adolescents and teenagers are also found, they could carry out the following activities:

1. Sensitize parents to reorientate their perception toward teaching profession so that their children who intend to go into the profession are encouraged and supported.

2. Organize excursions, workshop, seminars for students to sensitize and create awareness. By explaining to students the different careers and the need to see all professions as valuable and prestigious, this may help them to have positive perception towards teaching and other professions.

3. Counsellors need to work with government to improve the conditions of service of teachers so as to change the public negative perception of teachers. This could boost their morale, dedication to duty and attract more talented individual to the teaching profession.

4. Counsellor should give teachers counselling interventions to improve their self concept and confidence on the job in order to perform their duties with interest and dedication.

\section{Conclusion and Recommendations}

It is clear by implication that education is the key to individual and national development; teachers are needed to implement and achieve educational goals of primary, secondary and tertiary institutions. However, if they are neglected and undermined, teachers would be dissatisfied and frustrated on the job. Also, talented people would not be attracted to teaching profession. The results of the study revealed that sex did not influence education students' perception of teaching profession; most parents have negative attitude towards their children studying education; society does not perceive teaching as a noble and prestigious profession and poor condition of service prevent education students from going into teaching profession. The counselling implications were discussed in that the counsellor should perform activities involving students, parents and the society at large. Both parents and students should be sensitized on the need to encourage their children to study education and students to perceive teaching as a noble and prestigious profession; Government should improve the teaching conditions of teachers such as remuneration, promotion, environment among others to motivate teachers, boost their morale, confidence on the job and make the profession more attractive and prestigious. 


\section{References}

Abdulkareem, A.Y. (1997). The Teacher as a Manager. Ilorin Journals of Education, 17(1): 42-49.

Adeyemi, B.G. (2001). Strategic Manpower Development in Nigeria: New Challenges and Directions. Education and Society, 17(3).

Afe, J.O. (1990). A System Approach to the Organization. Supervision and Evaluation of Teaching Practice, in the Faculty of Education Seminar Series (1), 63-72. A Publication of the Faculty of Education, UNIBEN, Benin, Abmik Press.

Aghenta, J.A. (1981). The Economics of Teacher Education. The Case of the B.Ed. Degree in Nigeria. Journal of the Nigerian Educational Research Association, 2(1): 53-60.

Ajayi, K. (1982). Another look at the proposed New System of Secondary Education in Nigeria. Paper presented at the NERA Conference at University of Benin.

Asaya, S.A. (2000). Teaching Practice Handbook for student teachers.

Cassady, J.P. (2000). Teacher and teaching. London: David and Charles, First Edition.

Daniel, O. (2004). Problem Faced by Student Teacher during Teaching practice.

Ehiametalor, E.T. (1990). Business and Economics, Principles and Methods, 4(6): 31-39.

Ekhabefe, S.O. (2007). Towards Nigerian Educational Renaissance. New Era in Education, 17(1): 167.

Fafunwa, B.A. (1992). Professionalization of Teaching: A Philosophy for Nigerian Education. Ibadan: Heinemann Educational Books (Nig.) Ltd., 89-93.

Falade, G. (1995). Trade Unionism and Teaching Professionalism as impetus or National Development. A paper presented at the National Conference of Education NTI, Kaduna 26-28 September.

Federal Government of Nigeria (2004). National Policy on Education (Revised Edition). Abuja: NERDC Press.

Frankena, W.K. (1969). A philosophy of Education. New York: Collier Macmillan.

Hamachek, D.E. (1990). A Philosophy of Education, Learning and Growth (Fourth Edition), Allyn and Bacon.

National Policy on Education (2004). Federal Ministry of Education, Federal Government Press. Lagos, Nigeria.

Odunisi, T. (2004). The Challenges in the Teaching of Science. Midwest Unified Teachers' Journal, 5(3): 45-52.

Ogumogu (2006). Factors affecting the choice of education among unity (Unpublished).

Urevbu, A.O. (1991). Foundations and Methods of Education, Juland Education Publishers, Lagos. 